\title{
Teaching New Generation of Students. Millennials in the Hospitality \& Tourism Industry
}

\author{
Rahman bin Abdullah \\ UiTM Terengganu \\ Harnizam Zahari \\ UiTM Terengganu \\ Razlan Adli Zain \\ UiTM Terengganu \\ Nik Adnan Nik Mat \\ UiTM Terengganu \\ Nazarudin Derani \\ UiTM Terengganu \\ Mohamed Muneer Samsudin \\ UiTM Terengganu \\ Radzuan Noor Armia \\ UiTM Terengganu
}

\begin{abstract}
Millennials is the largest group of segmentation that is still studying and looking forward to join the workforce. Their characteristics, traits, needs and wants, and their ability and talents including their pool of resources available today (technology, internet, mass amount of online information) makes them a group that is going to influence the socioeconomic condition of a nation. The ability of an educator to better understand their condition would be able to alleviate their talent and ability in the right channel while not abusing the previous generation still in the workforce.
\end{abstract}

Keywords : Millennials, Hospitality, Tourism, education, workforce, characteristics

Teaching in the Hospitality and Tourism industry demands a good amount of physical and mental work. This is true considering the service nature of the industry and the call of fulfilling people's needs and demands, especially during the peak season. The ability to make the students understands the intangible aspect of the industry usually calls for a more practical approach, and the theory parts leads to much better comprehension in terms of their cognitive understanding. As such, teachers of the hospitality \& tourism industry should possess at least a basic understanding of the group of people that they are teaching in their many years of teaching. In current time, the Millennials is the largest group of segmentation that has been identified as the present-day student and the future of the industry. Hence, it is very important to understand and identify this particular generation so that their education's needs are fulfilled and their ability and talent being tap to their fullest potential. 


\section{THE MAIN CHARACTERISTICS OF THE GENERATION Y (MILLENNIALS)}

The Millennials are a very interesting group of people. Academic literature provide many discussions regarding this generation, but their specific behavior and characteristics have never been truly outlined ((Dawn and Powers, 2013).However, authors do agree on one part, namely the major event around which this generation is born and educated: the technological revolution and the rise of the Internet and mobile devices (Gurau, 2012). As a result, a first essential characteristic of Generation Y arises: the emergence of the modern means of communication is not a radical change from a previous lifestyle as it was for generation $\mathrm{X}$, but a new lifestyle itself (Nimon, 2007).

The Millennials have grown up with technology already in good place of the society, thus they possess a different set of interaction with peers and with information, as their attitude towards technology is very particular compared to previous generations (Pardue and Morgan, 2008). The new technology of communication are perceived as useful but not essential by the baby Boomers, generation $\mathrm{x}$, but the Millennials does not only see it as useful, but an essential tool in their daily life (Skiba, 2005). They live, some researchers believe, in perfect symbiosis with technology and it is as important to them as the clothes they wear or food they eat (Huntley, 2006)

Connectivity is of utmost importance when referring to Millenials (Novak, 2012), as for instance, connectivity plays a key role in the way the millennials perceive time (Cole and Schwartz, 2013). The use of messaging services and of search engines, such as Google, makes the millennials expect quick and immediate answers to problems and questions and this is impacting their personality on several levels: limited attention span, the disappearance of the border between private and public information and even the lack of punctuality (Howe and Strauss, 2000). From the same connectivity derives another specific trait of generation Y: its members develop strong relationships with the groups they belong to and these relationships are much stronger than the ones developed by other previous generations (Nimon, 2007). In the case of generation Y representatives, the researchers not only refer to the physical groups they interact with, but also to virtual groups they belong to, this generation being characterized by a high degree of globalism (Huntley, 2006).

Many studies have shown that only one out of three Millennials are Caucasian, thus Millennials are the most racially diverse generation (Talbott, 2012). The millenials support social causes and have a positive attitude towards those companies that are socially engaged. Researchers define them as well educated, technologically savvy, sophisticated, mature and with very powerful consumption tendencies, as a result from their particular form of interaction with technology (Powers and Valentine, 2013).

\section{VALUES AND LIFESTYLE}

The major difference between Millennials and the generations that precede it, including that of their parents (Baby Boomers) is the radical shift of values. Millennials are suprisingly much more tolerant, have traveled more than their parents and are socially engaged (Powers and Valentine, 2013). Since they are still young they have other priorities then the older members of the society they live in and they also have a very clear idea about what they deserve, great self-confidence and the desire to express their uniqueness (Talbott, 2012).

This generation have grown up in a period of economic boom and under the major influence of the so-called pop culture, which comprises of three main elements: social media, reality shows and internationalization (Parment, 2013). The worldwide influence of the pop culture has also local specificities determined by the historic event that marked this generation in every 
country or continent (Marcus, 1998) (in Romania this major event was nonetheless the 1989 Revolution). That is why, Millennials can be said to exist in every developed country. They have common features all throughout the world, such as their high acceptance of alternative lifestyles (domestic partnerships, relationships between same sex individuals), but also a set of specific, culturally determined values and attitudes (Schewe and Meredith, 2004).

The socialization of Millennials members occurred in a highly materialistic society, which sees consumption as evidence of financial strength and purchasing as a way of self-expression (Dong Hee and Soc Cheong, 2014). Millennials have access to above-average financial resources (which often come from family members) so that's why this generation has a socalled "possession obsession", characterized by materialism, status consumption and the strong influence of reference groups (Pinto et al., 2000). When making a purchase the Millennials consumer is very preoccupied by the way he is perceived by peers and groups he is part of or aspires to, this behavior being especially visible when it comes to the clothing, or cars they buy that cross the simple utility line and become status symbols (Parment, 2013). The millennials concern about self-image also influences their choice of life partner, as their materialism is often based on the so-called romantic motivation, briefly defined as -the desire to attract the most suitable partner" (Buss, 2003). Furthermore, studies show that as far the possession obsession is concerned, Millenials is quite heterogeneous, men being actually more inclined toward status consumption and luxury purchases then the women of this group (Stokburger-Sauer and Teichmann, 2011).

\section{ATTITUDE TOWARDS MEDIA AND EDUCATION}

Having grown up in an era of global, direct communication and media saturation, the millennials have become much more selective with the messages they choose to pay attention to (Powers and Valentine, 2013), thus these messages (promotional or not) need to be as customized and personal as possible (Talbott, 2012). That's why, besides understanding generation $Y$ from a psychographic perspective the literature has underlined the necessity to also understand and describe their specific media interaction patterns, different from the ones of the previous generation, $\mathrm{X}$, as classical communication channels will not have the same impact in their case and traditional advertising is facing the skepticism of these individuals (Pesquera, 2005). Even the use of email is somewhat outdated as millennials prefer services such as SMS or social networks that allow them to communicate quickly, in real time and they also prefer to connect to the Internet instead of watching TV (Engebretson, 2004).

Millennials specific attitude towards education is also considered a very interesting topic in the literature. As their specific traits influence to a great extent the way they perceive and relate to education in general and higher education in particular (Nimon, 2007). In this context the first specific characteristic of generation $Y$ is that its representatives are much more educated and they follow more education cycles during their lifetime then the representatives of the previous, X, generation for instance (Novak, 2012). Their education phases will move from undergraduate to postgraduate in the hospitality industry without any intervals in the working environment, which differ from Gen $\mathrm{x}$, take will take time to gain experience in the industry before pursuing postgraduate studies.

The technological revolution of the last century has also fundamentally changed the way millennial students learn and access information. If for previous generations these actions took a long time and used to involve visits to the library or gathering information from peers and groups, the millennials cherish the speed of accessing information using the Internet (websites like Wikipedia) as the main tool for information gathering (Ni mon, 2007). On the other hand, the usage of the Internet as a primary source of information, coupled with a certain lack of 
substance in the area of educational ethics can create top-level issues often materialized in the form of plagiarism cases (Beard, 2003). Therefore another concept arises in close correlation with how they relate to higher education, namely the so-called -academic integrity", defined briefly as intellectual honesty, based on five values: honesty, trust, justice, respect and responsibility (Cole and Schwartz, 2013).

Besides technology, the social conditions in which this generation was born and grew up (families that prioritize careers, planned pregnancies and highly desired and protected children) have also shaped the characteristics of the millennials, as they are considered special and protected from birth, hence the optimism and self-consciousness that characterizes them (Nimon, 2007). Their parents protective attitude and constant encouragement, determine these individuals to look at the whole educational process superficially and also believe they deserve everything, thus they don't accept advice or criticism from their professors lightly (Howe and Strauss, 2000). The Millennials students expect to literally have a say in their own education and cannot accept that certain things must be done in a certain way, following certain rules (Nimon, 2007). Hill (2002) believes that another very important aspect regarding the millennials is the fact that the environment they grew up in never promoted competition, thus the millennials don't feel they need to work hard in order to achieve something. That's why in school, most of the times they will settle for mediocre results, thus usually entering in conflicts with their professors (Hill, 2002).

In terms of an educational marketing perspective, group ethics have very important implications, so schools that exploit the feeling of affiliation to a group in favor of individual development, will be more sought by potential students (Nimon, 2007). In this context groups become primary sources of information and the institutions that use student representatives as spokespersons have a greater chance of attracting and retaining Millennials students (Huntley, 2006). These students will play a vital role in promoting the academic environment so it is very important that they have positive experiences at the universities where they attend. That's why researchers believe the educational process itself needs to change when it comes to these students who expect to be involved in their own education and learn in an innovative environment (Freestone and Mitchell, 2004).

Millenials also come with other features, the kind that might be described as "what they do not need any more of"-hovering, soccer moms, trophy children focus, entitlement, attachment, instant gratification, and rescuing. Simply stated, the existence of these phenomena is the stuff that can undermine classroom equity, create expectations-performance gaps, and foster a negative educational environment.

As millenials enter the workforce, four generations will be working together: traditionalists born before 1945, boomers born between 1945 and 1964, Generation X born between 1965 and 1981, and the millenials (Martin \& Tulgan, 2004). This merging of generations is more pertinent to educators than a strict focus on the millennials. This is particularly true if one considers education to be focused on lifetime learning or the learning of timeless skills rather than just a focus on timely information. The lifetime or timeless nature of education is required of millennials for learning to blend into a workforce that is not completely similar to them. It is incumbent on teachers to provide the necessary learning opportunities for knowledge and skills development valued by employers (Ackerman, Gross, \& Perner, 2003; Young \& Murphy, 2003). Thus, teaching to needs, not wants, is reinforced by this requirement. The ability to teach the hospitality students in practice and theory thus becomes a challenge to the current educators. However, the ability and the understanding of their traits, characteristics, needs and 
wants will eventually help educators better understand this group and alleviates their talents and cognitive ability.

\section{References}

Ackerman, D. S., Gross, B. L., \& Perner, L. (2003). Instructor, student and employer perceptions on preparing marketing students for changing business landscapes. Journal of Marketing Education, 21, 25-33.

Beard, F. (2003). College students attitudes towards advertising's ethical, economic and social consequences. Journal of Business Ethics, 48 (3): 217-228.

Buss, D. (2003). The Evolution of Desire: Strategies of Human Mating, 2nd edition. New York: Basic Books.

Cole M. and Schwartz L. (2013). Understanding academic integrity in the online learning environment: a survey of graduate and undergraduate business studen ts. ASBBS Anual Conference, 20(1). Las Vegas. [Online] Available from: http://asbbs.org/files/ASBBS2013/PDF/C/Cole_Swartz\%28738-746\%29.pdf

Dawn, V. and Powers, L. (2013). Generation Y Values and Lifestyle segments. Journal of consumer marketing, $.30(7):$ 597-606.

Dong Hee, K. and Soc Cheong, J. (2014). Motivational drivers for status consumption: a study of Generation Y consumers. International Journal of Hospitality Management, 38(April): 39-47.

Gurau, C. (2012). A lifestage analysis of consumer loyalty profile: comparing Generation X and Millenial consumers. Journal of Consumer Marketing, 29(2): 103-113.

Hill, R. (2002). Managing across generations in the 21st century: important lessons in the ivory trenches. Journal of Management Inquiry,11(1): 60-66.

Howe N. and Strauss, W. (2000). Millenials rising: The next great generation. New York: Vintage Books.

Huntley, R. (2006). The world according to Y: Inside the new adult generation. Crows Nest Australia: Allan and Unwin.

Marcus, C. (1998). A practical yet meaningful approach to customer segmentation. Journal of Consumer Marketing, 15(5): 494-504.

Engebretson, J. (2004). Odd gen out. American Demographics, 24(4): 14-18.

Freestone, O. and Mitchell, V. (2004). Generation Y attitudes towards e-ethics and internet-related missbehaviours. Journal of Business Ethics, 54(2): 121-128.

Martin, C., \& Tulgan, B. (2004). Managing the generation mix-Part II. Retrieved July 27, 2006, from www.topechelon.com

Nimon, S. (2007). Generation Y and Higher Education: the ither Y2K. Journal of institutional research, 13(1): 2441.

Novak, J. (2012). The six living generations in America. Marketing Teacher. [Online] Available from: http://www.marketingteacher.com/the-six-living-generations-in-america/

Pardue K. and Morgan P. (2008). Millennials considered: a new generation, new approaches and new implications for nursing education. National League for nursing, 29(2): 74-79.

Parment, A. (2013). Generation Y vs Baby Boomers: Shopping Behaviour, buyer involvement and implications for retailing. Journal of Retailing and Consumer Services, 20(2): 189-199.

Powers, Th. and Valentine, D. (2013). Generation Y values and lifestyle segments. Journal of consumer marketing, 30 (7), 597-606.

Schewe, C. and Meredith, G. (2004). Segmenting global markets by generational cohorts: determining motivation by age. Journal of Consumer Marketing, 4(1): 51-63.

Skiba, D. (2005). The millennials: have they arrived at your school of nursing? Nursing Education Perspectives, 26(6): 370-371.

Stokburger-Sauer, N. and Teichmann, K. (2011). Is luxury just a female thing? The role of gender in luxury brand consumption. Journal of Business Research, 66 :889-896 [Online] Available from:

http://www.lalondeconference.org/CB/2011_lalonde_seminar/papers/Paper_163_STOCKBURGE

R_TEICHMANN.pdf 
Talbott, S. (2012). Generation Y and sustainability. University of Tennesse Honor Thesis project, 1-38. [Online] Available from: http://trace.tennessee.edu/cgi/viewcontent.cgi?article=2506\&context=utk chanhonoproj

Pinto, M., Parente, D. and Palmer, T. (2000). Materialism and credit card use by college students. Psychological reports, 86(2): 643-652.

Young, M. R., \& Murphy, J. W. (2003). Integrating communications skills into the marketing curriculum: A case study. Journal of Marketing Education, 25, 57-70. 